\title{
Radiation Response of Bacteria Associated with Human Cancellous Bone
}

\author{
Naznin Akhtar ${ }^{1 *}$, Fahmida Binte Atique ${ }^{2}$, Md Mamun Miah ${ }^{1}$, and \\ S. M. Asaduzzaman ${ }^{1}$ \\ ${ }^{I}$ (Tissue Banking and Biomaterial Research Unit, Atomic Energy Research Establishment, Savar, Dhaka, \\ Bangladesh) \\ ${ }^{2}$ (Department of Genetic engineering and Biotechnology, North South University, Dhaka, Bangladesh)
}

\begin{abstract}
Cancellous bones from twenty five live tissue donors were tested for bacterial contamination and initial bioburden ranged from $4.1 \times 10^{1}$ to $3.1 \times 10^{3}$ cfu/g (average $9.0 \times 10^{2} \mathrm{cfu} / \mathrm{g}$ ). Forty six representative bacterial isolates were characterized on the basis of morphological, cultural and biochemical characteristics. Staphylococcus spp. was found to be predominant contaminant in tissue samples (41.30\%). To assess the radiation resistance all the bacterial isolates were exposed to 1 to $10 \mathrm{kGy}$ gamma radiation from ${ }^{60} \mathrm{Co}$ gamma source. The radiation decimal reduction dose values $\left(D_{10}\right)$ and twelve log reduction values $(12 \mathrm{D}$ value $)$ of the isolates were calculated. $D_{10}$ values of the isolates were ranged from 0.59 to $1.20 \mathrm{kGy}$. Among the studied bacterial isolates, Streptococcus spp. was the most radioresistant isolates $\left(D_{10}\right.$ value 0.93-1.20 kGy) and three of the Streptococcus spp. survived up to $8 \mathrm{kGy}$. All the bacterial isolates were killed at $9 \mathrm{kGy}$. Twelve log reduction value $(12 \mathrm{D}$ value) of the most resistant isolate was $14.4 \mathrm{kGy}$. These results indicate that standard radiation sterilization dose $(25 \mathrm{kGy})$ is satisfactory for the sterilization of the cancellous bone allografts.
\end{abstract}

Keywords- Bioburden, Cancellous bone, Radiation resistance, Staphylococcus, Streptococcus, Sterilization

\section{Introduction}

Bone allografts play an important role in treating bone defects and in recovering the mobility of patients suffering from bone and joint diseases. In Bangladesh, a large number of patients have been suffering from different types of bone diseases like degenerative bone diseases, congenital deformities, fractures, nonunion, and bone loss from traumatic accidents etc. Consequently the demand of bone allografts is increasing sharply. Though tissue allografts can dramatically improve the quality of life of the recipients and can even save lives, there is always a potential risk of disease or infection transmission from the donor to the recipient with the use of allografts [1-3]. So, the microbiological quality of the bone graft is the most important consideration for its clinical application.

To minimize the risk of diseases transmission, gamma radiation is currently the most common method for sterilization of tissue allografts [4,5]. Conventionally, $25 \mathrm{kGy}$ gamma radiation is used for the sterilization of tissue allografts. However, there is still much discussion on the doses of radiation required and any detrimental effects of radiation on the bone [6-9]. The sterilization dose required may vary from specimen to specimen and from country to country, although there are recommended standard dose for this purpose [10]. In radiation sterilization practice, it is important to determine the radiation resistance of the bioburden, because radiation dose necessary to achieve sterility assurance level (SAL of $10^{-6}$ ) can be calculated based on the initial microbial contamination level and the radiation resistance of the contaminant [11]. Information on the type and magnitude of microbial contamination associated with bone allografts are limited in our country. Therefore, this work was undertaken to evaluate the bacterial contaminants of human bone tissues and to assess the radiation resistance of the isolates.

\subsection{Tissue procurement}

\section{Materials and methods}

Bone samples were collected from twenty five live tissue donors from twelve hospitals of Bangladesh through the donation of femoral heads removed during total hip replacement, hemiarthoplasty and traumatic limb amputation surgery. All the tissues were collected by the written consent of donor. The ages of donors were ranged from 40 to 75 years. All donors were pre-screened for the presence of transmissible diseases (eg. HIV, HBV and VDRL) and the tissues were excised under aseptic conditions in operation theatre. Immediately after harvesting, the bones were wrapped with gamma sterilized polyethylene pack, labeled with donor ID and were kept in a freezer $\left(-40^{\circ} \mathrm{C}\right)$ in the operation theatre. Then the bones were placed in a cool box filled with ice slabs and were transported immediately to tissue banking laboratory using AC vehicle. 


\subsection{Bioburden assessment}

Bacterial contaminants of the bone samples were determined by direct inoculation of the tissue wash on nutrient agar medium. Swab test and membrane filtration were not considered due to the known poor efficiency of recovery for Swab-based method [12-14] and the cleaning of bone tissue was not suitable for filtration. Because the cleaning of skeletal tissue yields turbid oily solutions containing blood, marrow and fat residues, which tend to occlude the $0.45 \mu \mathrm{m}$ pore membranes quite rapidly. Therefore, for the assessment of bioburden, bones were first thawed to room temperature and then aseptically immersed in $200 \mathrm{ml}$ sterile distilled water in sterile glass beakers separately. The tissue containing jars were shaken at $100 \mathrm{rpm}$ for 15 minutes using mechanical shaker. Bioburden was determined from the tissue wash by pour plate and spread plate method using nutrient agar plate (three plates for each). After $24-72$ hours of incubation at $37^{\circ} \mathrm{C}$, bacterial colonies were counted and the results were expressed in cfu/g of bone. Representative bacterial isolates were sub-cultured on nutrient agar to obtain pure culture.

\subsection{Characterization of bacterial isolates}

Bacterial isolates were characterized on the basis of gram staining, cell shape and cell arrangement. Preliminary identification of bacterial isolates was carried out on the basis of morphological, cultural and biochemical behavior according to Bargey's "Manual of Determinative Bacteriology" [15]. The percent occurrence of different types of bacteria was also calculated.

\subsection{Radiation response of the isolates}

Bacterial isolates were tested for their resistance to different doses of gamma radiation. The bacterial cultures were grown in nutrient broth to a final density of about $10^{8}$ cells per ml. The cells were suspended in saline water and were exposed to $1-10 \mathrm{kGy}$ gamma radiation at dose rate of $5.84 \mathrm{kGy} / \mathrm{hr} .{ }^{60} \mathrm{Co}$ gamma irradiator of Institute of Food and Radiation Biology (IFRB), at Atomic Energy Research Establishment (AERE), Savar, Dhaka was used as gamma source. For each irradiation dose, bacterial colony was counted before and after gamma irradiation. Survival fraction (S) of bacteria, for each radiation dose, was calculated by dividing the number of viable cells after irradiation $(\mathrm{N})$ by the initial viable cell number $\left(\mathrm{N}_{0}\right)$. Survival curve of each group of bacteria was obtained by plotting $\log \mathrm{S}$ versus irradiation doses. $\mathrm{D}_{10}$ values were calculated according to the equation: $\mathrm{D}_{10}$ value $=\mathrm{D} /\left(\log _{10} \mathrm{~N}_{0}-\log _{10} \mathrm{~N}\right)$, Where $\mathrm{D}=$ Radiation dose, $\mathrm{N}_{0}=$ Untreated viable cell number, $\mathrm{N}=$ Irradiated viable cell number.

\section{Results}

All the studied bone samples (twenty five) were contaminated by bacteria. Bacterial count varied from $4.1 \times 10^{1} \mathrm{cfu} / \mathrm{g}$ to $3.1 \times 10^{3} \mathrm{cfu} / \mathrm{g}$ (average $9.0 \times 10^{2} \mathrm{cfu} / \mathrm{g}$ ). Types of bacterial contaminants are presented in Table- 1 . Most of the isolates were gram-positive cocci $(82.22 \%)$. Gram-negative bacteria were not found. Forty six bacterial isolates from the bone samples were characterized based on their morphological, cultural character and biochemical tests. Most frequently found bacterial contaminant was staphylococci $(41.30 \%)$ and streptococci (36.95\%). Eight gram positive bacilli (B6, B24, B25, B29, B30 and B38-B40) were identified as Bacillus spp. Among the thirty eight gram positive cocci, nineteen isolates (B4, B8-B10, B13, B18-B21, B27, B34-B37, B42, B43, B46, B47 and B50) were identified as Staphylococcus spp and two isolates (B15 and B41) were Micrococcus spp. Seventeen catalase negative cocci (B2, B3, B5, B7, B11, B12, B14, B17, B22, B23, B28, B31-B33, B44, B45 and B48) were identified as Streptococcus spp.

Table-1: Type of bacterial contaminants in bone samples

\begin{tabular}{cc}
\hline Microorganism & $\begin{array}{c}\text { Isolation frequency } \\
\text { Number }(\mathbf{\%})\end{array}$ \\
\hline Gram-negative cocci & Nil \\
Gram-negative rod & Nil \\
Bacillus spp. & $8(17.39)$ \\
Staphylococcus spp. & $19(41.30)$ \\
Micrococcus spp. & $2(4.35)$ \\
Streptococcus spp. & $17(36.95)$ \\
\hline
\end{tabular}

All the forty six bacterial isolates, comprising 4 genera, were screened for radiation resistance with ${ }^{60} \mathrm{Co}$ gamma rays at ambient temperature $\left(25 \pm 2^{0} \mathrm{C}\right)$ in normal saline and percentage of bacteria survived at different doses of gamma irradiation were calculated (Table-2). Among the 46 bacterial isolates, 45 (97.82\%) isolates were survived up to $5 \mathrm{kGy}, 31(67.39 \%)$ isolates were survived up to $6 \mathrm{kGy}, 21(45.65 \%)$ isolates were survived up to $7 \mathrm{kGy}$ and $3(6.52 \%)$ isolates were survived up to $8 \mathrm{kGy}$ gamma irradiation. All the bacterial contaminants were 
completely eliminated after exposure to $9 \mathrm{kGy}$ gamma irradiation. Streptococcus spp were the most radioresistant bacteria and three isolates (B2, B7 and B45) of this genus were survived up to $8 \mathrm{kGy}$. Isolate B9, which belonged to the genus Staphylococcus, was the most radiosensitive bacteria and was killed by $5 \mathrm{kGy}$ gamma irradiation.

Table-2: Radiation response of bacterial isolates

\begin{tabular}{llllllll}
\hline Type of bacteria & $\begin{array}{l}\text { Total number } \\
\text { of isolates }\end{array}$ & \multicolumn{7}{c}{ Survive up to radiation dose (kGy) } \\
\cline { 2 - 8 } & & 4 & 5 & 6 & 7 & 8 & 9 \\
\hline Bacillus spp. & 8 & 8 & 8 & 8 & 4 & Nil & Nil \\
Staphylococcus spp. & 19 & 19 & 18 & 5 & Nil & Nil & Nil \\
Micrococcus spp. & 2 & 2 & 2 & 1 & Nil & Nil & Nil \\
Streptococcus spp. & 17 & 17 & 17 & 17 & 17 & 3 & Nil \\
\hline Total & 46 & 46 & 45 & 31 & 21 & 3 & Nil \\
\hline \% Survival & & $100 \%$ & $97.82 \%$ & $67.39 \%$ & $45.65 \%$ & $6.52 \%$ & $0.00 \%$ \\
\hline
\end{tabular}

Survival curves for bacterial isolates following exposure to several doses of gamma radiation were obtained by plotting the logarithm of survival fractions $\left(\log _{10} \mathrm{~S}\right)$ versus radiation doses $(\mathrm{kGy}) . \log _{10} \mathrm{~S}$ values of the isolates at each data point were very close, so overlapping lines were obtained in the survival curve (Fig.1-4). The radiation decimal reduction dose values $\left(\mathrm{D}_{10}\right.$ value) and twelve log reduction values (12 D value) of the isolates are presented in Table-3. $\mathrm{D}_{10}$ values of Bacillus spp. were ranged from 0.82-0.98 kGy. In case of Staphylococcus spp. $\mathrm{D}_{10}$ values were in the range of 0.59-0.89 kGy. $\mathrm{D}_{10}$ values of Micrococcus spp. were 0.70 and $0.86 \mathrm{kGy}$. Relatively higher $\mathrm{D}_{10}$ values (0.93-1.20 kGy) were recorded for Streptococcus spp. The lowest $\mathrm{D}_{10}$ value $(0.59$ $\mathrm{kGy}$ ) was recorded for the isolate B9 (Staphylococcus sp.) and the isolate B7 (Streptococcus sp.) was the most resistant isolate with a $D_{10}$ value of $1.20 \mathrm{kGy}$. To achieve sterility assurance level (SAL) $10^{-6}$, twelve log reduction of the contaminants is required for tissue samples contaminated with $10^{6} \mathrm{cfu}$ per gram. Therefore, 12 D-value of the isolates were also calculated. 12 D value of the bacterial isolates was 7.08 to14.44 kGy (Table-3).

Table 3: $D_{10}$ values and $12 \mathrm{D}$ values of bacterial isolates

\begin{tabular}{lll}
\hline Bacteria & $\mathbf{D}_{\mathbf{1 0}}$ value $(\mathbf{k G y})$ & 12 D value $(\mathbf{k G y})$ \\
\hline Bacillus spp. & $0.82-0.98$ & $9.84-11.76$ \\
Micrococcus spp. & $0.70-0.86$ & $8.40-10.32$ \\
Staphylococcus spp. & $0.59-0.89$ & $7.08-10.68$ \\
Streptococcus spp. & $0.93-1.20$ & $11.16-14.44$ \\
\hline
\end{tabular}

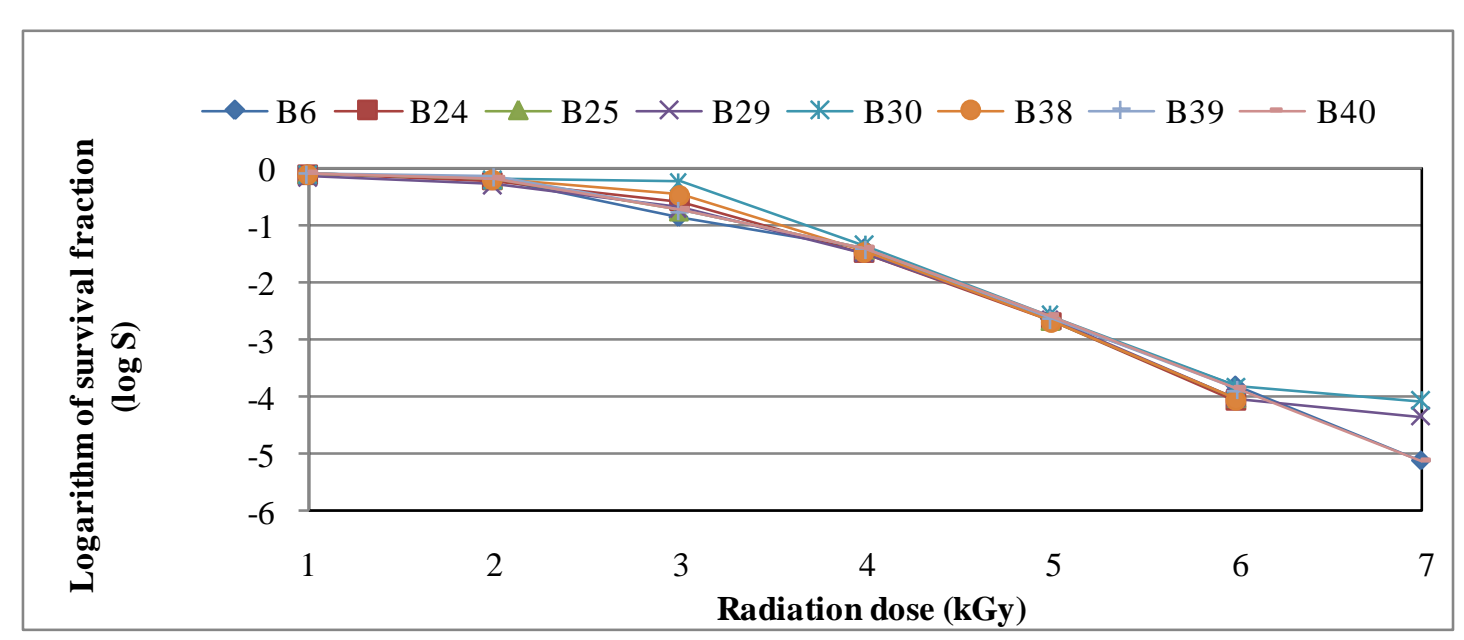

Fig-1: Survival curve of eight isolates (B6, B24, B25, B29, B30 and B38-B40) of Bacillus spp. Four isolates (B24, B25, B38 and B39) survived up to $6 \mathrm{kGy}$ and another four (B6, B29, B30 and B40) survived up to $7 \mathrm{kGy}$. 


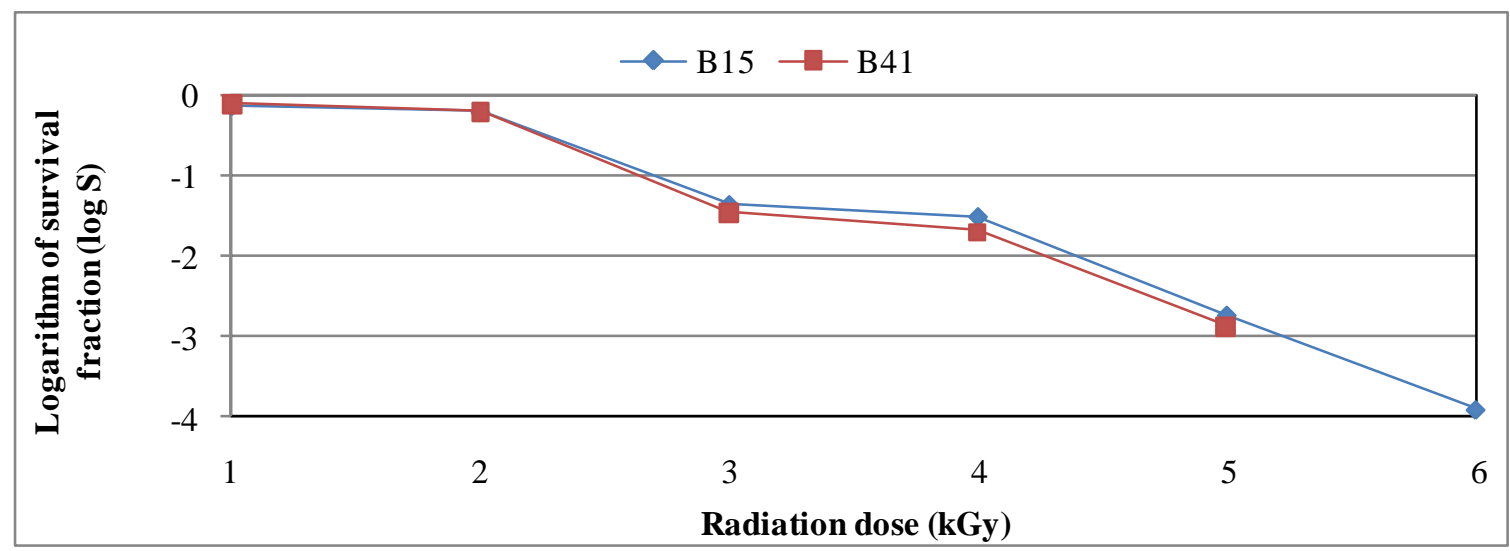

Fig.-2: Survival curve of two isolates (B15 and B41) of Micrococcus spp. Isolate B41 survived up to 5 kGy and B15 survived up to $6 \mathrm{kGy}$.

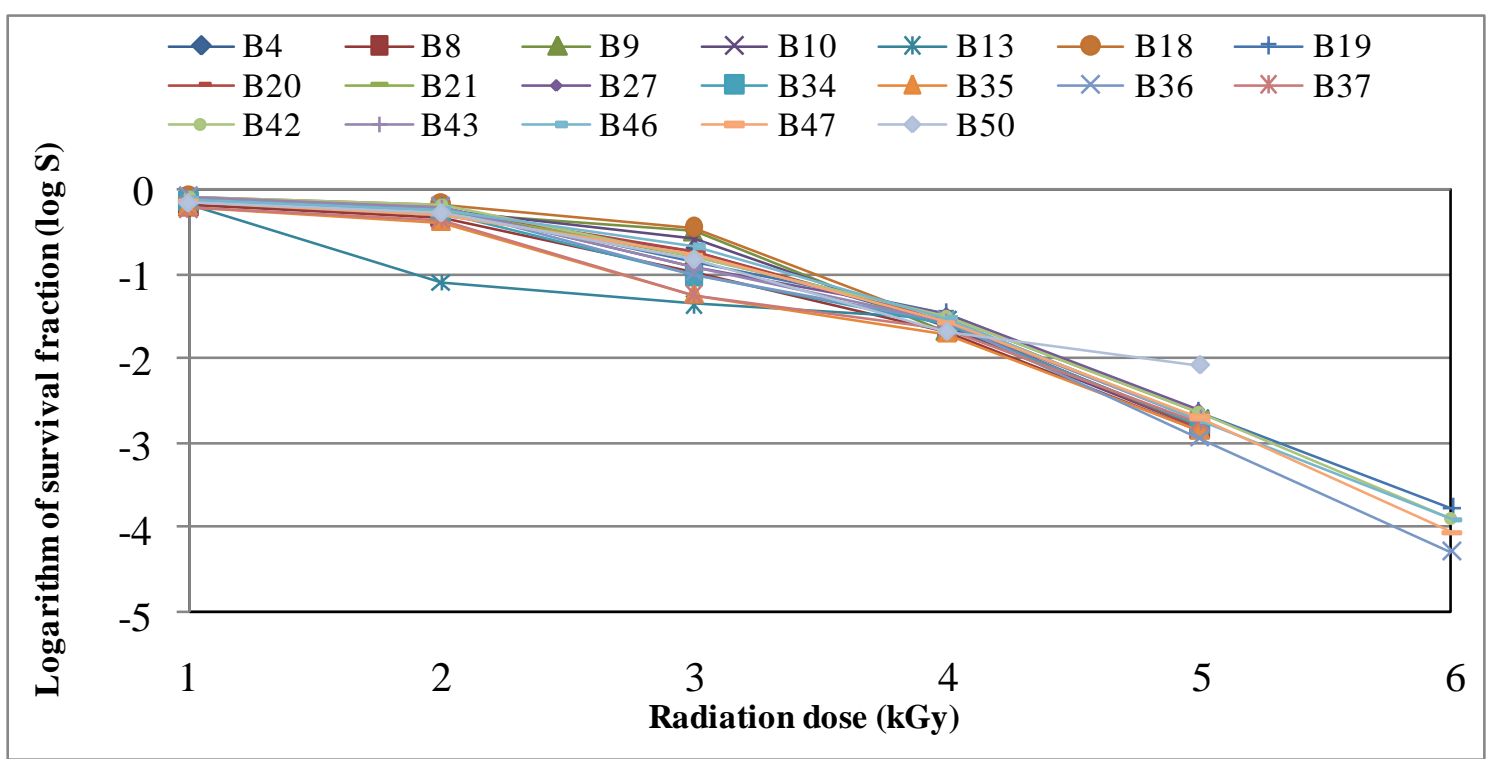

Fig.-3: Survival curve of nineteen isolates (B4, B8-B10, B13, B18-B21, B27, B34-B37, B42, B43, B46, B47 and B50) of Staphylococcus spp. One isolate (B9) survived up to $4 \mathrm{kGy}$, thirteen ((B4, B8, B10, B13, B18, B20, B21, B27, B34, B35, B37, B43 and B50) survived up to $5 \mathrm{kGy}$ and five (B19, B36, B42 and B47) survived up to $6 \mathrm{kGy}$.

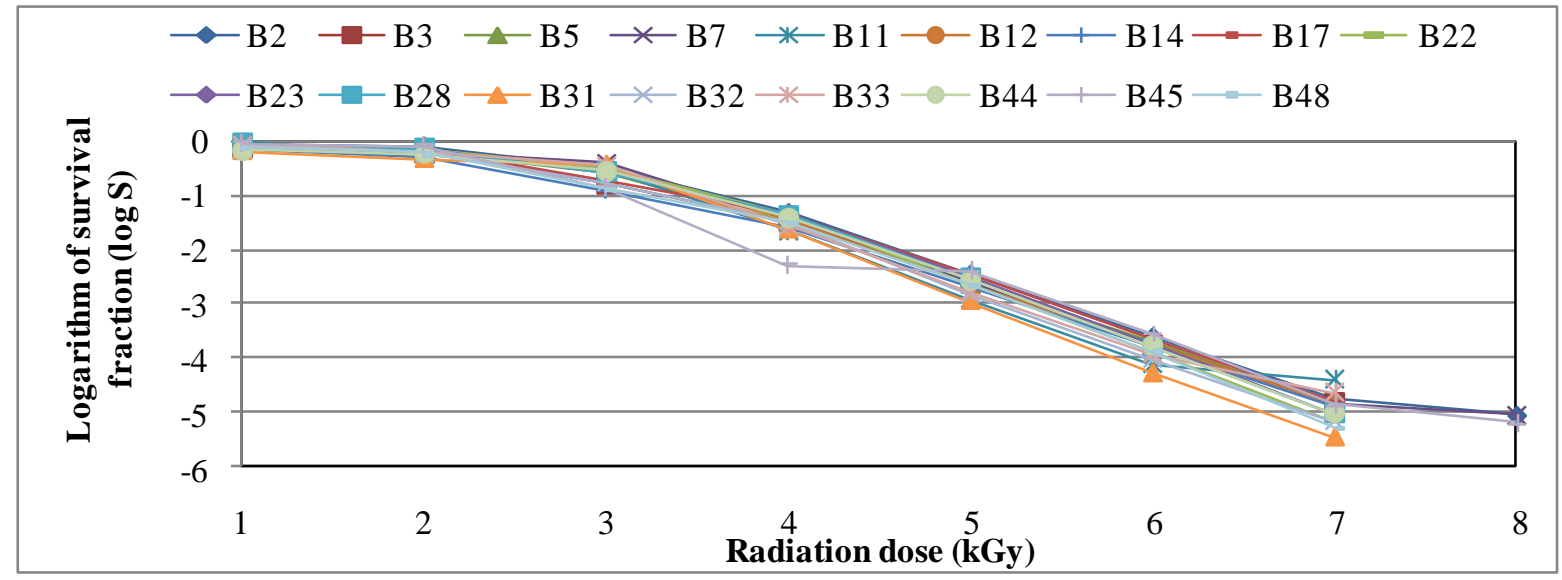

Fig.-4: Survival curve of seventeen isolates (B2, B3, B5, B7, B11, B12, B14, B17, B22, B23, B28, B31-B33, B44, B45 and B48) of Streptococcus spp. Fourteen isolates (B3, B5, B11, B12, B14, B17, B22, B23, B28, B31B33, B44 and B48) survived up to $7 \mathrm{kGy}$ and three isolates (B2, B7 and B45) survived up to $8 \mathrm{kGy}$. 


\section{Discussion}

Transmission of diseases or infections from the donor to the recipient is always a risk in allograft transplantation. Many authors reported about infection following allograft implantation [7, 12, 16, and 17]. Wang et al. [18] reported that approximately one-half of the infections associated with human tissue transplants were due to bacterial agents and of that, $90 \%$ were aerobic organisms. The best way to avoid infection or diminish its incidence is careful donor selection and the application of sterile techniques in tissue procurement, processing and storage. Varettas and Taylor [19] considered bioburden assessment as a small but integral part of the allograft bone processing, which combine with other good tissue banking practices would provide safe allograft bone for transplantation. Therefore, our focus was on the assessment of bacterial load associated with unprocessed human bone and determination of radiation response of the isolates.

All the bone samples used in this experiment were collected from seronegative (HIV, HBV, and VDRL) donor and were procured under aseptic condition. In spite of following good tissue banking practice, donor tissues were not sterile. Average bacterial count was $9.0 \times 10^{2} \mathrm{cfu} / \mathrm{g}$ (ranged from $4.1 \times 10^{1}$ to $3.1 \times 10^{3}$ cfu/g). Many authors [19-21] had reported different rate of contamination in bone tissues. In our study, most of bone samples were contaminated with Staphylococcus spp. Streptococcus spp. was the second highest contaminant. Ibrahim et al. [24] also reported coagulase negative staphylococci as major contaminant in bone allografts and twelve of their bone allografts were contaminated with streptococci. In many studies, bacterial contaminant in bone tissues was predominantly skin flora [19-23]. Though the isolates found in this study are comparable with the previous reported studies, it was difficult to determine the source of contamination in these tissue samples. Microbial contamination may arise from the donor at the time of retrieval, or from the environment and the personnel during processing [25]. Deijkers et al. [26] divided contaminating organisms into low and high pathogenicity. They considered organisms of low pathogenicity to be skin commensals and organisms of high pathogenicity were thought to be originated from endogenous sources in the donor, which more likely to cause infection in the recipient.

Generally, $25 \mathrm{kGy}$ gamma irradiation is used for terminal sterilization of tissue allografts. As gamma radiation adversely affects the mechanical and biological properties of bone allografts, some tissue bank prefer lower dose without compromising a SAL of $10^{-6}$. Baker et al. [27] has found that sterility (10 $\left.0^{-6} \mathrm{SAL}\right)$ of tissue allograft could be achieved using at least $9.2 \mathrm{kGy}$ gamma radiation, and in another study $15 \mathrm{kGy}$ gamma radiation was substantiated as radiation sterilization dose (RSD) for frozen bone allografts [28]. Radiation dose necessary to achieve SAL of $10^{-6}$ depends on the initial microbial contamination level and the radiation resistance of the contaminant. To observe the radiation effects, bacterial isolates were exposed to different doses of gamma radiation and $\mathrm{D}_{10}$ values was calculated in this study. We found that, $\mathrm{D}_{10}$ values of bacterial isolates ranged from 0.57 to $1.2 \mathrm{kGy}$. Streptococcus spp. was the most radioresistant isolates ( $\mathrm{D}_{10}$ value $\left.0.93-1.2 \mathrm{kGy}\right)$ and three of the Streptococcus spp. survived up to $8 \mathrm{kGy}$. All the bacterial isolates were killed at $9 \mathrm{kGy}$.

In a sterilization process, the nature of microbiological death or reduction is described by an exponential function. Therefore, the number of microorganisms which survive in a sterilization process can be expressed in terms of probability. While the probability may be reduced to a very low number, it can never be reduced to zero. For the sterilization of medical and pharmaceutical product, maximum probability of a single nonsterile unit in $10^{6}$ units is widely accepted. Therefore, if the bioburden on an article were one million, $12 \mathrm{log}$ reduction of the initial bioburden is required to achieve a $10^{-6}$ probability of a nonsterile unit. Though the initial bioburden of the studied bone samples ranged from $4.1 \times 10^{1}$ to $3.1 \times 10^{3} \mathrm{cfu} / \mathrm{g}$, to ensure patients safety, $12 \mathrm{log}$ reduction was calculated. In this study, twelve log reduction value (12D value) of the most resistant isolate was $14.4 \mathrm{kGy}$. From these findings, it is clear that the standard sterilization dose of $25 \mathrm{kGy}$ gamma radiation was adequate for the sterilization of these tissue allografts and a lower dose might also be acceptable. To determine lower radiation sterilization dose (RSD), further study may therefore be suggested using radioresistant reference strain.

\section{Conclusion}

Microbial contamination in musculoskeletal tissue graft is a serious concern in rehabilitative surgery. To minimize the chance of contamination, in addition to select seronegative donor, good tissue banking practice should be implemented in tissue procurement, processing and storage. However, aseptic processing practices can reduce but not eliminate all microbial contaminants of tissue. To prevent the risk of diseases transmission from donor origin, terminal sterilization is an integral part of allograft preparation. The choice of RSD depends on the microbial contamination level and the radiation response of the contaminant. In our study, average bioburden was $9.0 \times 10^{2} \mathrm{cfu} / \mathrm{g}$ and maximum radiation resistance $\left(\mathrm{D}_{10}\right.$ value) was $1.20 \mathrm{kGy}$ and $12 \mathrm{D}$ value of the most resistant isolate was $14.4 \mathrm{kGy}$. Based on the average bioburden and radiation response of the contaminants, $25 \mathrm{kGy}$ gamma radiation was found to be ample to ensure sterility of cancellous bone allografts. 


\section{References}

[1] W.W. Tomford, Transmission of disease through transplantation of musculoskeletal allografts, J Bone Joint Surg Am, 77, 1995, 1742-1754.

[2] D.P. Grogan, V. Kalen, K.J. Ross-Guidera, and L.I. Pugh, Use of allograft bone for posterior spinal fusion in idiopathic scoliosis, Clin Orthop, 369, 1999, 273-278.

[3] D.M. Ehrler, and A.R. Vaccaro, The use of allograft bone in lumbar spine surgery, Clin Orthop, 371, $2000,38-45$.

[4] G.O. Phillips, Radiation technology in surgery and the pharmaceutical industry: an overview of applications, IAEA bulletin, 36, 1994, 19-23.

[5] N. Yusof, The use of gamma irradiation for sterilization of bone and amnion, Malaysian Journal of Nuclear Science, 12, 1994, $243-251$.

[6] M.A. Kainer, J.V. Linden, D.N. Whaley, H.T. Holmes, W.R. Jarvis, D.B. Jernigan, and L.K.. Archibald, Clostridium infections associated with musculoskeletal-tissue allografts, New Engl J Med, 350, 2004, 2564-2571.

[7] T. Eastlund, Bacterial infection transmitted by human tissue allograft transplantation, Cell Tissue Banking, 7(3), 2006, $147-166$.

[8] H. Nguyen, and D.A.F. Morgan, Sterilization of allograft bone: is $25 \mathrm{kGy}$ the gold standard for gamma irradiation?, Cell Tissue Banking, 8, 2007, 81-91.

[9] C.R. Balsly, A.T. Cotter, L.A. Williams, B.D. Gaskins, M.A. Moore, and L. Wolfinbarger, Effect of low dose and moderate dose gamma irradiation on the mechanical properties of bone and soft tissue allografts, Cell Tissue Banking, 9, $2008,289-298$.

[10] IAEA, Radiation sterilization of medical products, Proc. of an IAEA symposium, Bombay, 1974, $139-187$.

[11] R.N. Mukherjee, Recommendation for the sterilization of medical products: Radiosterilization of Medical Products, Proc. of the symposium of IAEA on ionizing radiation for sterilization of medical products and biological tissues, Bombay, India, 1974, 513523.

[12] M.R. Veen, R.M. Bloem, and P.L. Petit, Sensitivity and negative predictive value of swab cultures in musculoskeletal allograft procurement, Clin Orthop Relat Res, 300, 1994, 259-263.

[13] S.B. Vehmeyer, R.M. Bloem, R.L. Deijkers, M.R. Veen, and P.L. Petit, A comparative study of blood and bone marrow cultures in cadaveric bone donation, J Hosp Infect 43(4), 1999, 305-308.

[14] S.B. Vehmeyer, R.M. Bloem, and P.L. Petit, Microbiological screening of post-mortem bone donors- two case reports, J Hosp Infect 47(3), 2001, 193-197.

[15] J.G. Holt, N.R. Krieg, H.A. Sneath, J.T. Staley, and S.T. William, Bergey's Manual of Determinative Bacteriology $9^{\text {th }}$ edn. (Baltimore: Williams and Wilkins, 1994)

[16] H.J. Mankin, F.J. Hornicek, and K.A. Raskin, Infection in massive bone allografts, Clin Ortho Relat Res, 432, $2005,210-216$.

[17] W. Tomford, J. Thongphasuk, H.J. Mankin, and M.J. Ferraro, Frozen musculoskeletal allografts: A study of the clinical incidence and causes of infection associated with their use, J Bone Joint Surg (American Volume) 72(8), 1990, 1137-1143.

[18] S. Wang, C. Zinderman, R. Wise, and M. Braun, Infections and human tissue transplants: review of FDA MedWatch reports 20012004, Cell Tissue Banking 8(3), 2007, 211-219.

[19] K. Varettas, and P. Taylor, Bioburden assessment of banked bone used for allografts, Cell Tissue Bank 12 (1), $2011,37-43$.

[20] S.F. Journeaux, N. Johnson, S.L. Bryce, S.J. Friedman, S.M.M. Sommerville, and D.A.F. Morgan, Bacterial contamination rates during bone allograft retrieval, J Arthroplast, 14(6), 1999, 677-681.

[21] S.M.M. Sommerville, N. Johnson, S.L. Bryce, S.F. Journeaux, and D.A.F. Morgan, Contamination of banked femoral head allograft: incidence, bacteriology and donor follow up, Aust NZJ Surg, 70, 2000, 480-484.

[22] S.B.W. Vehmeyer, R.M.S. Arnoud, R.M. Bloem, and P.L.C. Petit, Bacterial contamination of femoral head allografts from living donors, Acta Orthop Scand, 73(2), 2002, 165-170.

[23] F. Judas, L. Teixeira, and A. Proenca, Coimbra university hospitals' bone and tissue bank: twenty-two years of experience, Transpl Proc, 37(6), 2005, 2799-2801.

[24] T. Ibrahim, H. Stafford, C.A.N. Esler, and R.A. Power, Cadaveric allograft microbiology. International Orthopaedics (SICOT), 28, 2004, 315-318.

[25] N. Yusof, Quality system for the radiation sterilization of tissue allografts, in G.O. Phillips, D.M. Strong, R. Von-Versen, and A. Nather (Eds), Advances in Tissue banking, 3 (Singapore: World Scientific, 1999) 257-281.

[26] R.L.M. Deijkers, R.M. Bloem, P.L.C. Petit, R. Brand, S.B.W. Vehmeyer, and M.R. Veen, Contamination of bone allografts: analysis of incidence and predisposing factors, J Bone Joint Surg Br, 79, 1997, 161-166.

[27] T.F. Baker, C.J. Ronholdt, and S. Bogdansky, Validating a low dose gamma irradiation process for sterilizing allografts using ISO 11137 method 2B, Cell Tissue Bank 6(4), 2005, 271-275.

[28] H. Nguyen, D.A. Morgan, L.I. Sly, M, Benkovich, S. Cull, and M.R. Forwood, Validation of 15 kGy as a radiation sterilization dose for bone allografts manufactured at the Queensland Bone Bank: application of the VDmax 15 method, Cell Tissue Bank 9(2), 2008, 139-147. 